\title{
A study on fetomaternal outcome in premature rupture of membranes
}

\author{
Arnab Mondal*, Sanhita Kanungo \\ Department of Obstetrics and Gynecology, KPC Medical College and Hospital, Kolkata, West Bengal, India
}

Received: 09 February 2018

Accepted: 19 February 2018

\section{*Correspondence:}

Dr. Arnab Mondal,

E-mail: arnabbon@gmail.com

Copyright: $\odot$ the author(s), publisher and licensee Medip Academy. This is an open-access article distributed under the terms of the Creative Commons Attribution Non-Commercial License, which permits unrestricted non-commercial use, distribution, and reproduction in any medium, provided the original work is properly cited.

\begin{abstract}
Background: Premature rupture of membranes (PROM) is a common obstetric complication. This condition may lead to maternal complications like puerperal hemorrhage, puerperal sepsis, chorioamnionitis, maternal death etc. due to increased risk of infections and operative interventions. It may also lead to neonatal complications like prematurity, respiratory distress syndrome (RDS), sepsis, low birth weight (LBW) and perinatal death. The aim of the study was to find out whether certain maternal and neonatal complications were significantly higher in PROM cases than controls. Methods: In the present study, the definition of PROM adopted is - rupture of fetal membranes before the onset of true labor pain. The lower limit of gestational age was taken to be 28 weeks. Diagnosis of PROM was mainly clinical. Culture sensitivity test of amniotic fluid was done. The mother was observed throughout labor and postnatal period till discharge and any complications were noted. The baby was also observed from birth till discharge and any complications and interventions were noted. Data obtained was analysed by appropriate statistical methods to obtain results and reach the conclusion.

Results: The results of the study showed that the incidence of puerperal hemorrhage, LBW babies, prematurity, maternal morbidities, chorioamnionitis, perinatal mortality and neonatal morbidities were significantly higher in PROM cases. These results corroborated with the findings of other researchers most of the time.

Conclusions: It was concluded that individualized management of PROM cases depending on the gestational age and risk of complications is the best way to achieve a good fetomaternal outcome in such cases.
\end{abstract}

Keywords: Complications, Fetomaternal, Membranes, Premature, Rupture

\section{INTRODUCTION}

PROM is a challenging problem to the obstetricians. During the last few decades, many clinical risk factors of PROM have been identified and the fetomaternal outcome has improved due to better management.

When membranes rupture before the onset of labor, it is known as premature rupture of membranes (PROM). When PROM occurs before 37 completed weeks of gestation it is termed as preterm premature rupture of membranes (p PROM). ${ }^{1}$ In $10-15 \%$ of PROM cases approaching term, labor may be delayed by more than 24 hours (prolonged rupture of membranes). In such cases, fetomaternal complications are substantial.

The latent period (time interval between rupture of membranes and onset of labor) is directly proportional to the incidence of infection. Chorioamnionitis resulting from PROM may be life threatening.

Maternal complications in PROM are increased due to sepsis and increased need for operative interventions. Perinatal complications are raised due to sepsis, gestational immaturity and asphyxia. This study aims at studying the fetomaternal complications in PROM. 


\section{METHODS}

This cross-sectional case control study was conducted in the Department of Obstetrics and Gynecology, KPC Medical College and Hospital, Kolkata, over a period of 1 year from $1^{\text {st }}$ December 2014 till 30 ${ }^{\text {th }}$ November 2015.

The study group consists of 100 cases with PROM with duration of gestational period beyond 28 completed weeks. The control group consists of 100 cases having rupture of membranes after the onset of true labor pain with duration of gestational period beyond 28 weeks. In both the groups, both booked and unbooked cases were included.

Diagnosis of PROM was done from history, clinical examination and investigations. In all cases, liquor amnii was collected with Sim's speculum, intracervical and high vaginal swabs and in cases of caesarean section, by amniocentesis just before making uterine incision. The samples were subjected to gram staining and aerobic culture and sensitivity test for detection of microorganisms.

Conditions of the mother and the fetus and the progress of labor (in both study and control groups) were monitored clinically at regular intervals and recorded in detail. Induction or augmentation of labor, lower uterine caesarean section, low forceps or ventouse operation were done where required. Condition of the baby at birth was observed and recorded as Apgar score at 1 and 5 minutes after birth. Birth weight and weight at discharge were recorded. Any interventions and complications were recorded till discharge. Maternal conditions and complications (if any) after delivery, till the time of discharge were observed and recorded.

Collected data were tabulated and analysed using Chi Square Test. ${ }^{2}$ In all cases $p$ value $<0.05$ was taken to be significant.

\section{RESULTS}

There was no case of maternal mortality both in the study and control groups.

Table 1: Incidence of post partum hemorrhage (P.P.H) in PROM cases and controls.

\begin{tabular}{|lll|} 
& $\begin{array}{l}\text { No. of patients } \\
\text { with P.P.H. }\end{array}$ & $\begin{array}{l}\text { No. of patients } \\
\text { without P.P.H. }\end{array}$ \\
\hline PROM & $11(11 \%)$ & 89 \\
\hline Control & $2(2 \%)$ & 98 \\
\hline
\end{tabular}

Table 1 shows that the incidence of P.P.H. is higher in PROM cases than controls. A chi square test done on Table 1 shows that for the obtained Chi Square value (6.68) and degree of freedom (df) 1 , the $p$ value is $<0.05$. Hence the higher incidence of P.P.H. in PROM group compared to controls is statistically significant. Here the
P.P.H. cases were all managed conservatively (10 units of Oxytocin infusion, intravenous Methergin and/or intramuscular prostaglandin injection, uterine massage). Blood transfusion was required in 4 cases of P.P.H. in PROM cases.

Table 2: Incidence of puerperal morbidity in study and control groups.

\begin{tabular}{|lll|} 
Group & $\begin{array}{l}\text { Morbid } \\
\text { puerperium }\end{array}$ & $\begin{array}{l}\text { Normal } \\
\text { puerperium }\end{array}$ \\
\hline Study & $30(30 \%)$ & 70 \\
\hline Control & $7(7 \%)$ & 93 \\
\hline
\end{tabular}

Puerperal morbidities included in Table 2 were P.P.H., puerperal sepsis, puerperal pyrexia, vulval hematoma, non-union of abdominal and perineal wounds etc. From Table 2 it appears that puerperal morbidity increases in PROM cases. The chi square test done on Table 2 shows that, for the obtained chi square value and df $1, \mathrm{p}$ value was $<0.05$. Hence the higher incidence of puerperal morbidity in PROM group compared to controls is statistically significant.

Table 3: Incidence of chorioamnionitis in the study and control groups.

\begin{tabular}{|lll|}
\hline & $\begin{array}{l}\text { Chorioamnionitis } \\
\text { positive }\end{array}$ & $\begin{array}{l}\text { Chorioamnionitis } \\
\text { negative }\end{array}$ \\
\hline PROM & $30(30 \%)$ & $70(70 \%)$ \\
\hline Control & $3(3 \%)$ & $97(97 \%)$ \\
\hline
\end{tabular}

Study of liquor amnii revealed a large number of patients with features of chorioamnionitis in PROM cases $(30 \%)$ as seen in Table 3. It appears that PROM invites ascending infection leading to chorioamnionitis and intra amniotic infection. The chi square test done on Table 3 shows that, for the obtained Chi Square value and df $1, p$ value was $<0.05$. Hence the higher incidence of chorioamnionitis in PROM group compared to controls is statistically significant.

Table 4: Incidence of chorioamnionitis in relation to gestational period in PROM cases.

\begin{tabular}{|lll|}
$\begin{array}{l}\text { Gestational } \\
\text { period }\end{array}$ & $\begin{array}{l}\text { Chorioamnionitis } \\
\text { positive }\end{array}$ & $\begin{array}{l}\text { Chorioamnionitis } \\
\text { negative }\end{array}$ \\
\hline Preterm & $12(57.14 \%)$ & 9 \\
\hline Term & $18(22.22 \%)$ & 63 \\
\hline
\end{tabular}

From Table 4 it is apparent that the incidence of chorioamnionitis was higher in preterm PROM cases than in term PROM cases. The causes may be longer latent period, increased number of vaginal examinations, poor capacity of the fetus to fight against infection etc. The chi square test done on Table 4 shows that, for the obtained chi square value (9.78) and df $1, \mathrm{p}$ value was $<0.05$. Hence the incidence of chorioamnionitis is significantly higher in preterm than term patients in PROM group. 
Table 5: Micro organisms detected in high vaginal and cervical swabs in study cases and controls.

\begin{tabular}{|lll|}
\hline $\begin{array}{l}\text { Names of } \\
\text { microorganisms detected }\end{array}$ & $\begin{array}{l}\text { No. of } \\
\text { PROM cases }\end{array}$ & $\begin{array}{l}\text { No. of } \\
\text { control } \\
\text { cases }\end{array}$ \\
\hline Escherisia coli & 33 & 4 \\
\hline Staphylococcus aureus & 14 & 4 \\
\hline Enterobacter & 7 & - \\
\hline Klebsiella pneumoniae & 7 & 4 \\
\hline Diptheroids & 6 & - \\
\hline Pseudomonas & 13 & 7 \\
\hline Non-pathogenic organisms & 25 & 81 \\
\hline
\end{tabular}

In Table 5, we found that the most predominant organism detected in this study was Escherisia coli, next common was Staphylococcus aureus. In the control group, only a small number of cases showed presence of pathogenic bacteria in the vaginal swab.

Table 6: Incidence of low birth weight (LBW) babies in PROM and control series.

\begin{tabular}{|llll|}
\hline & $\begin{array}{l}\text { Total no. of } \\
\text { babies born }\end{array}$ & $\begin{array}{l}\text { Birth weight } \\
<2.5 \mathrm{~kg} \\
\text { (LB W) }\end{array}$ & $\begin{array}{l}\text { Birth } \\
\text { weight } \\
\geq 2.5 \mathrm{~kg}\end{array}$ \\
\hline PROM & 102 & $24(23.5 \%)$ & $78(76.5 \%)$ \\
\hline Control & 100 & $10(10 \%)$ & $90(90 \%)$ \\
\hline
\end{tabular}

Table 6 suggests that the incidence of LBW babies was higher in PROM cases than controls.

The chi square test done on Table 6 shows that, for the obtained chi square value (6.6) and df 1, p value was $<0.05$. Hence the higher incidence of LBW babies in the PROM group compared to controls is statistically significant.

Table 7: Incidence of preterm babies in study and control series.

\begin{tabular}{|lll|}
\hline & $\begin{array}{l}\text { Preterm babies }(<37 \\
\text { completed weeks })\end{array}$ & $\begin{array}{l}\text { Term babies }(\geq 37 \\
\text { completed weeks })\end{array}$ \\
\hline Study & $21(20.6 \%)$ & 81 \\
\hline Control & $8(8 \%)$ & 92 \\
\hline
\end{tabular}

Table 7 shows that the incidence of preterm babies was higher in PROM cases than controls. The chi square test done on Table 7 shows that, for the obtained chi square value (6.51) and df $1, \mathrm{p}$ value was $<0.05$. Hence the higher incidence of preterm babies in PROM group compared to controls is statistically significant.

Table 8: Incidence of small for gestational age (SGA) babies in study and control series.

\begin{tabular}{|lll|}
\hline & SGA & Others \\
\hline Study & $3(2.9 \%)$ & 99 \\
\hline Control & $2(2 \%)$ & 98 \\
\hline
\end{tabular}

Table 8 shows that the incidence of SGA babies is higher in PROM group than controls. The chi square test done on Table 8 shows that, for the obtained chi square value $(0.18)$ and df $1, p$ value was $>0.05$. Hence the higher incidence of SGA babies in PROM group is not statistically significant.

Table 9: Perinatal mortality in study and control groups.

\begin{tabular}{|c|c|c|c|}
\hline & $\begin{array}{l}\text { Total } \\
\text { no. }\end{array}$ & $\begin{array}{l}\text { Perinatal deaths } \\
\text { (Stillborn and death } \\
\text { within } 1^{\text {st }} \text { week of } \\
\text { birth) }\end{array}$ & $\begin{array}{l}\text { No. of } \\
\text { babies } \\
\text { surviving } \\
\text { finally }\end{array}$ \\
\hline PROM & 102 & $10(4+6)(\mathrm{PMR}=9.8 \%)$ & 92 \\
\hline Control & 100 & $2(1+1)(\mathrm{PMR}=2 \%)$ & 98 \\
\hline
\end{tabular}

Table 9 shows that Perinatal Mortality Rate (PMR) is much higher in women with PROM (9.8\%) than in controls (2\%). The chi square test done on Table 9 shows that, for the obtained chi square value (5.5) and df $1, \mathrm{p}$ value was $<0.05$. Hence the higher perinatal mortality in PROM group than controls is statistically significant.

Table 10: Perinatal mortality in PROM cases in relation to birth weight.

\begin{tabular}{|lll|}
\hline Birth weight & $\begin{array}{l}\text { No. of perinatal } \\
\text { deaths (stillborn }+1^{\text {st }} \\
\text { week deaths) }\end{array}$ & $\begin{array}{l}\text { No. of babies } \\
\text { surviving } \\
\text { finally }\end{array}$ \\
\hline $2.5 \mathrm{~kg}(24)$ & $7(3+4)(\mathrm{PMR}=29.17 \%)$ & 17 \\
\hline $2.5 \mathrm{~kg}(78)$ & $3(1+2)(\mathrm{PMR}=3.85 \%)$ & 75 \\
\hline
\end{tabular}

Table 10 shows that the PMR is higher among Low Birth Weight babies $(29.17 \%)$ compared to babies with birth weight $\geq 2.5 \mathrm{~kg}(3.85 \%)$. The chi square test done on Table 10 shows that, for the obtained chi square value and df $1, \mathrm{p}$ value was $<0.05$. Hence the higher perinatal mortality in LBW babies than babies with birth weight $\geq 2.5 \mathrm{~kg}$ in PROM group is statistically significant.

\section{Table 11: Perinatal mortality in PROM cases in relation to latent period.}

\begin{tabular}{|lll|}
$\begin{array}{l}\text { Latent } \\
\text { period }\end{array}$ & $\begin{array}{l}\text { Death }\left(\text { stillborn }+1^{\text {st }}\right. \\
\text { week deaths) }\end{array}$ & $\begin{array}{l}\text { No. of babies } \\
\text { surviving } \\
\text { finally }\end{array}$ \\
\hline Upto 24 hours & $3+4=7(\mathrm{PMR}=11.11 \%)$ & 56 \\
\hline$>24$ hours & $1+2=3(\mathrm{PMR}=50 \%)$ & 3 \\
\hline
\end{tabular}

Two twin babies included in the series were of Extremely Low Birth Weight (ELBW) and died on the first neonatal day. It is observed from Table 11 that the PMR is higher when latent period exceeds $24 \mathrm{hrs}(50 \%)$ than when the latent period is upto $24 \mathrm{hrs}(11.11 \%)$. The Chi Square test done on Table 11 shows that, for the obtained Chi Square value (6.67) and df $1, \mathrm{p}$ value was $<0.05$. Hence the higher perinatal mortality when the latent period exceeds $24 \mathrm{hrs}$ than when it is $<24$ hrs in PROM group is statistically significant. 
Table 12: Incidence of neonatal morbidity in study and control groups.

\begin{tabular}{lll} 
Group & $\begin{array}{l}\text { No. of patients with } \\
\text { neonatal complications }\end{array}$ & $\begin{array}{l}\text { No. of normal } \\
\text { neonates }\end{array}$ \\
Study & $24(23.5 \%)$ & 78 \\
\hline Control & $4(4 \%)$ & 96
\end{tabular}

Neonatal complications which were included in Table 12 were sepsis, conjunctivitis, pneumonia, skin infection etc. From this table, it appears that incidence of neonatal complications is higher in PROM group. The Chi Square test done on Table 12 shows that, for the obtained Chi Square value and df $1, \mathrm{p}$ value was $<0.05$. Hence the higher incidence of neonatal complications in PROM group compared to controls is statistically significant.

\section{DISCUSSION}

\section{Maternal complications}

\section{Maternal mortality}

Maternal mortality in the present study was nil in both study and control groups. Nevertheless, maternal death in PROM cases is distinctly possible, mostly because of infections, operative interventions and post partum hemorrhage. . $^{3,4}$

\section{Maternal morbidities}

\section{Postpartum hemorrhage}

P.P.H. in PROM cases was found to be significantly higher than in controls in the present study (Table 1). The higher incidence of P.P.H. in PROM cases may be due to prolonged labor, increased instrumental vaginal delivery, atonic uterus, coagulation failure (rarely), etc. Of the 11 cases, 4 patients required blood transfusion. In the control group, only 2 cases of P.P.H. were recorded and none required blood transfusion. So, it is concluded that P.P.H. is significantly more common among PROM cases and often severe enough requiring blood transfusion. Calkins LA and Sanyal MK reported higher incidence of P.P.H. in PROM cases. ${ }^{5,6}$

\section{Puerperal morbidities}

Higher incidence of other puerperal morbidities was seen in PROM cases $(30 \%)$ compared to controls (7\%), which was statistically significant (Table 2). So, it is concluded that puerperal morbidities increase in PROM cases, mostly due to operative interventions and infections. Sanyal MK (32.5\%) and Kodkany BS reported higher incidence of puerperal morbidities in PROM cases. ${ }^{6,7}$

\section{Chorioamnionitis}

The present study shows that the incidence of chorioamnionitis was significantly higher in PROM group (30\%) than the control series (3\%) (Table 3 and 4). Pathogens detected were similar to those found in vaginal and cervical swabs (Table 5). So, it is evident that PROM cases invite ascending infections which lead to chorioamnionitis. The incidence of chorioamnionitis amongst preterm PROM (57.14\%) was significantly higher than the incidence of chorioamnionitis in term PROM (22.22\%) (Table 4). This trend is comparable to the results obtained by Beydoun SN (58.6\% in patients with PROM before 28 weeks and $<22 \%$ after 36 weeks of pregnancy). ${ }^{8}$ Guzick DS reported incidence of chorioamnionitis in $33 \%$ of preterm deliveries. ${ }^{9}$ In the present series, the higher incidence of chorioamnionitis noted in preterm deliveries with PROM was due to higher incidence of infections in cases of preterm deliveries following PROM than when membranes ruptured after the onset of labor.

Micro-organisms detected in high vaginal and cervical swabs in PROM cases (Table 5). The commonest microorganism isolated from the genital tracts of patients with PROM was E. coli (33\%) followed by Staphylococcus aureus (14\%). However, due to lack of facilities, organisms more commonly implicated in PROM like Ureaplasma urealyticum, Chlamydia trachomatis, Mycoplasma hominis and a wide variety of anaerobes could not be identified in the present study. The incidence of vaginal and cervical colonization reported by different workers are as follows: Anaerobes - Peptostreptococcus, Clostridia and Bacteroides species- 50\% (Miller JM and Bobitt JR), Chlamydia trachomatis- 44\% (Alger LS), Ureaplasma urealyticum- 42\% (McDonald HM), Group B streptococcus $-16 \%$ (Alger LS), Enteropathogens like E. coli and Klebsiella - 13\% (McDonald HM), Staphylococcus aureus - 3\% (McGregor JA). ${ }^{10-15}$

\section{Perinatal complications}

Perinatal outcome is the centre point of major controversies in PROM. Complications of newborn babies delivered after PROM are mainly due to prematurity, prolonged effect of oligohydramnios and infections.

\section{$L B W$, prematurity and SGA babies}

In the present study, the incidence of LBW and prematurity is significantly higher in PROM than controls (Table 6-8). The incidence of prematurity in PROM reported by Calkins LA, Taylor ES and Gunn GC ranged between $9-40 \%$ with an average of $20 \%$ and is comparable with the finding of $20.6 \%$ in the current study. 5,16,17 The higher incidence of SGA among PROM patients was not statistically significant.

\section{Perinatal mortality}

In the present study, the PMR was nearly 5 times higher amongst babies born out of PROM cases than controls (Table 9-11). The PMR was much higher among LBW 
babies when compared with babies weighing $\geq 2.5 \mathrm{~kg}$ born out of PROM cases. The PMR found in the present series in PROM group $(9.8 \%)$ closely simulates the incidence reported by Gunn GC in his series. ${ }^{17}$ Whereas Taylor ES reported lowest PMR as $1.5 \%$, it was Flower CE who reported the highest PMR as $36.7 \%$ in $1958 .{ }^{16,18}$ The wide variation in perinatal mortality was due to inclusion of PROM cases at different durations of gestation including preterm and pre-viable PROMs and availability of facilities in the respective neonatal care units. Sanyal MK reported the PMR as $4.2 \% .^{6}$ The present study shows that when latent period increases, PMR is significantly higher among PROM cases. This was also observed by Embrey MP, Gunn GC. ${ }^{17,19}$ Christensen KK had a contrary opinion where they showed that perinatal mortality improved by prolonging the pregnancy by 10 days. $^{20}$

\section{Neonatal morbidities}

It may be concluded from the present study that PROM significantly increases neonatal morbidities (Table 12). These neonatal morbidities are mainly related to sepsis and are called infectious neonatal morbidities, which were evident in $23.5 \%$ of PROM cases in the present study. Similar infectious neonatal morbidities were reported by various studies ranging between $0.5-25 \% .^{21}$

\section{CONCLUSION}

The following observations were made from the present study:

- Though there was no incidence of maternal mortality, but the incidence of puerperal maternal morbidities, P.P.H. and chorioamnionitis was significantly increased in PROM cases.

- Incidence of chorioamnionitis was significantly higher in PROM cases and the commonest organism implicated was E. coli followed by Staphylococcus aureus.

- The incidence of chorioamnionitis amongst preterm PROM cases was significantly higher than the incidence of chorioamnionitis in term PROM cases.

- Incidence of Low Birth Weight (LBW) and preterm babies was significantly higher among PROM cases.

- Perinatal Mortality Rate was significantly higher among PROM cases.

- Perinatal mortality was significantly higher in LBW babies of PROM cases than babies weighing $\geq 2.5 \mathrm{~kg}$ in the same group.

- Perinatal mortality was significantly higher in neonates of PROM patients with latent period longer than 24 hours.

- Infectious neonatal morbidities were significantly higher in neonates of PROM patients compared to controls.

The present study shows that maternal and neonatal morbidities as well as perinatal mortality are significantly higher in the PROM group compared to controls. Hence it may be concluded that careful identification of present or impending complications, and individualizing the management based on gestational age and the presence or likelihood of these complications currently holds best hopes for optimizing fetomaternal outcome in PROM cases.

\section{ACKNOWLEDGMENTS}

Authors would like to acknowledge to all doctors and staff of Department of Obstetrics and Gynecology, KPC Medical College and Hospital for their sincere support and help.

\section{Funding: No funding sources \\ Conflict of interest: None declared \\ Ethical approval: Not required}

\section{REFERENCES}

1. McParland PC, Taylor DJ, Bell SC. Mapping of zones of altered morphology and choriodeciduaic connective tissue cellular phenotype in human fetal membranes (amnion and deciduas) overlying the lower uterine pole and cervix before labor at term. Am J Obstet Gynecol. 2003;189:1481-4.

2. Park K. Health information and basic medical statistics. In: Park K. Park's textbook of preventive and social medicine. $22^{\text {nd }}$ ed. Jabalpur: M/s Banarsidas Bhanot;2013:795-6.

3. Lebherz TB, Hellman LP, Madding R, Anctil A, Arje SL. Double-blind study of premature rupture of the membranes. Am J Obstet Gynecol. 1963 Sep;87(2):218-25.

4. Moretti M, Sibai BM. Maternal and perinatal outcome of expectant management of premature rupture of membranes in the midtrimester. Am J Obstet Gynecol. 1988 Aug;159(2):390-6.

5. Calkins LA. Premature spontaneous rupture of the membranes. Am J Obstet Gynecol. 1952 Oct;64(4):871-7.

6. Sanyal MK, Mukherjee TN. Premature rupture of membranes an assessment from a rural medical college of West Bengal. J Obstet Gynaecol India. 1990;40(5):623-8.

7. Kodkany BS, Telang MA. Premature rupture of membranes - a study of 100 cases. J Obstet Gynecol India. 1991;41:492-6.

8. Beydoun SN, Yasin SY. Premature rupture of membranes before 28 weeks: conservative management. Am J Obstet Gynecol. 1986 Sep;155(3):471-9.

9. Guzick DS, Winn K. The association of chorioamnionitis with preterm delivery. Obstet Gynecol. 1985 Jan;65(1):11-6.

10. Miller JM, Hill GB, Welt SI, Pupkin MJ. Bacterial colonization of amniotic fluid in the presence of ruptured membranes. Am J Obstet Gynecol. 1980 Jun;137(4):451-8. 
11. Bobitt JR, Hayslip CC, Damato JD. Amniotic fluid infection as determined by transabdominal amniocentesis in patients with intact membranes in premature labor. Am J Obstet Gynecol. 1981 Aug; 140(8):947-52.

12. Alger LS, Lovchik JC, Hebel JR, Blackmon LR, Crenshaw MC. The association of Chlamydia trachomatis, Neisseria gonorrhoeae, and group B streptococci with preterm rupture of the membranes and pregnancy outcome. Am J Obstet Gynecol. 1988 Aug;159(2):397-404.

13. McDonald HM, O'Loughlin JA, Jolley P, Vigneswaran R, McDonald PJ. Prenatal microbiological risk factors associated with preterm birth. Br J Obstet Gynaecol. 1992 Mar;99(3):190-6.

14. McDonald HM, O'Loughlin JA, Jolley P, Vigneswaran R, McDonald PJ. Vaginal infection and preterm labour. $\mathrm{Br}$ J Obstet Gynaecol. 1991 May;98(5):427-35.

15. McGregor JA, French JI, Richter R, Franco-Buff A, Johnson A, Hillier $\mathrm{S}$ et al. Antenatal microbiologic and maternal risk factors associated with prematurity. Am J Obstet Gynecol. 1990 Nov;163(5 pt 1):1465-73.

16. Taylor ES, Morgan RL, Bruns PD, Drose VE. Spontaneous premature rupture of fetal membranes. Am J Obstet Gynecol. 1961 Dec;82(6):1341-8.
17. Gunn GC, Mishell DR Jr, Morton DG. Premature rupture of the fetal membranes. A review. Am J Obstet Gynecol. 1970 Feb;106(3):469-83.

18. Flowers CE, Donnelly JF, Creadrick RN, Greenberg BG, Wells HB. Spontaneous premature rupture of the membranes. Am J Obstet Gynecol. 1958 Oct;76(4):761-72.

19. Embrey MP. On the strength of the fetal membranes. Br J Obstet Gynaecol. 1954 Dec;61(6):793-6.

20. Christensen KK, Christensen P, Ingmarsson I, Mardh PA, Nordenfelt E, Ripa $\mathrm{T}$ et al. A study of complications in preterm deliveries after prolonged premature rupture of the membranes. Obstet Gynecol. 1976 Dec;48(6):670-7.

21. Lamont RF, Fisk N. The role of infection in the pathogenesis of preterm labour. In: Studd J. Progress in obstertrics and gynaecology. Volume 10. New York: Churchill Livingstone; 1995:140-1.

Cite this article as: Mondal A, Kanungo S. A study on fetomaternal outcome in premature rupture of membranes. Int J Reprod Contracept Obstet Gynecol 2018;7:897-902. 